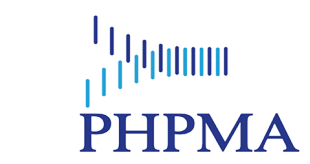

Published by

Department of Public Health and Preventive

Medicine, Faculty of Medicine,

Udayana University

\section{Knowledge about sources and benefits of vitamin $D$ among high school students in Bandung, Indonesia}

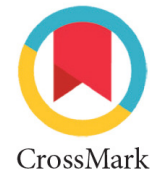

Reina Syafira Gisrianti, ${ }^{1}$ Vycke Yunivita Dewi, ${ }^{2}$ Edhyana Sahiratmadja ${ }^{2 *}$

\title{
ABSTRACT
}

${ }^{1}$ Faculty of Medicine, Universitas Padjadjaran, Bandung 2Department of Biomedical Science, Faculty of Medicine, Universitas Padjadjaran, Bandung, Indonesia

\footnotetext{
*Correspondence to:

Edhyana Sahiratmadja; Department of Biomedical Science, Faculty of Medicine, Universitas Padjadjaran, Bandung,

Indonesia;

e.sahiratmadja@unpad.ac.id
}

Background and purpose: Indonesia is a tropical country, located through the equator line which is abundantly exposed with sun. However, vitamin D deficiency among population in Indonesia is common. To increase optimal vitamin D intake, knowledge on vitamin $D$ and the role of sun exposure early in the adolescence period is imperative. This study aims to explore the knowledge of high school students about the sources and benefits of vitamin D.

Methods: This was a quantitative analytical study with a cross-sectional design using survey method, conducted in 2019. A public madrasah high school in Bandung, Indonesia, was selected using convenience sampling. A validated questionnaire was distributed to students aged 16-18 years old, containing of two parts about sources of vitamin D (10 questions) and its benefits (4 questions).

Results: In total, 198 high school students participated in the study, majoring in Natural Sciences (55.6\%) and Social Sciences (44.4\%), of whom $76.3 \%$ were females. The proportion of students who answered correctly about vitamin D was $72.8 \%$, whereas $61.9 \%$ had correct answers about the sources of vitamin D and $83.8 \%$ about its benefits. Female students had significantly higher score compared to males $(p<0.001)$. Interestingly, the Natural Science students had no significant higher score compared to Social Science students $(p=0.227)$.

Conclusion: The knowledge about the source of vitamin D and its benefit among female high school students is significantly better than males, thus, special attention to male students is needed. There is a trend, although not significant, that the knowledge of students majoring in the Natural Sciences is higher compared to the Social Sciences. This study suggests the need of an integrative health education and outdoor activities, as well as a better nutrition program, focusing especially on male students and the Social Sciences class.

Keywords: knowledge, vitamin D, health education, sun exposure

Cite This Article: Gisrianti, R.S., Dewi, V.Y., Sahiratmadja, E. 2021. Knowledge about sources and benefits of vitamin D among high school students in Bandung, Indonesia. Public Health and Preventive Medicine Archive 9(2): 80-84. D0I: 10.15562/ phpma.v9i2.384

\section{INTRODUCTION}

Vitamin D is a very important nutrient for calcium and phosphorus absorption, which is vital for bone growth in maintaining bone resorption and mineralization. Furthermore, vitamin $\mathrm{D}$ has a role to regulate immune cells, to increase insulin secretion from the pancreas, and to control more than 200 genes for proliferation, differentiation, and apoptosis of cells in the body. ${ }^{1,2}$ The source of vitamin $\mathrm{D}$ is predominantly ( 80 to $90 \%$ ) from sun light, whereas foods and supplements are accounted for only about $20 \% .^{3}$
The optimal serum vitamin D concentration for the body is around $\geq 30-32 \mathrm{ng} / \mathrm{mL}$, and those with lower than optimal serum concentration is considered as having vitamin D deficiency (21-29 $\mathrm{ng} / \mathrm{mL})$ or insufficiency $(\leq 20 \mathrm{ng} / \mathrm{mL}){ }^{4}$ Data from Chinese National Nutrition and Health Survey (CNNHS) 2010-2012 showed that $50 \%$ male and $56.5 \%$ female children and adolescents aged 6-17 years old have vitamin D deficiency. ${ }^{5}$ Vitamin D deficiency usually occurs in countries that have four seasons. Surprisingly, the serum levels of vitamin D of individual living in Indonesia, a tropical country with abundantly enough sunlight, is low. ${ }^{6}$ The
2013 South East Asian Nutrition Survey (SEANUTS) data revealed that more than $50 \%$ of Indonesians experience vitamin D insufficiency and only $5 \%$ of children have sufficient vitamin D. ${ }^{7}$ Moreover, a study in Depok, Indonesia reported that $85.2 \%$ females and $9.1 \%$ males have vitamin D deficiency. ${ }^{8}$

In children and adolescents, who are in their growth period, vitamin D deficiency can inhibit bone growth and they also have a higher risk of developing rickets and osteoporosis later in life., ${ }^{910}$ Maintaining adequate vitamin $\mathrm{D}$ and calcium is recognized as an important way of preventing osteoporosis and fractures. 
In adolescents, there is a peak of growth where the need for vitamin $\mathrm{D}$ is increasing. Furthermore, vitamin D deficiency increases risks of chronic diseases such as cancer, diabetes mellitus, autoimmune and infection. ${ }^{3,11}$ The Institute of Medicine (IOM) 2011 recommended that an estimated average requirement for vitamin $\mathrm{D}$ in adolescents aged 9-18 years is 400 IU $(10 \mu \mathrm{g} /$ day $)$. Therefore, the need for vitamin $\mathrm{D}$ is the highest in the period of childhood and adolescence. ${ }^{12-14}$

During the growth spurt period, which is the peak of height growth and also the peak of bone mass growth, the need for calcium and vitamin $\mathrm{D}$ is increased. ${ }^{15}$ The average accumulation of bone minerals reaches its peak around the age of 16 years old, therefore, it is important to maximize bone mineralization in this period. ${ }^{16}$ The fact that the adolescents are accounted for $21 \%$ total population in Indonesia, ${ }^{15}$ therefore, fulfilment of nutritional needs among the adolescents is important to achieve.

The serum levels of vitamin $\mathrm{D}$ are influenced by several factors, among others age, gender, lifestyle, and season. ${ }^{17}$ The lifestyle or behaviour of a person is influenced by knowledge about vitamin D itself. Therefore, knowledge about vitamin $\mathrm{D}$ is an essential pre-requirement in fulfilling the need of vitamin $\mathrm{D}$, and this knowledge is influenced by education, occupation, age, gender, environment and socio-cultural factors. ${ }^{18}$ A study showed that the knowledge about sources of vitamin $\mathrm{D}$ and its benefits among general population in Indonesia is lacking. ${ }^{19}$

High school students are mostly in the age of adolescence. In Indonesia, the major classes taken by high school students are Natural Sciences or Social Sciences. The Natural Sciences classes teach more biological topics compared to the Social Science classes, whereas Social Science classes have an elective topic in Biology. Therefore, differences in the type of education as well as gender difference may affect the knowledge. This study aims to explore the knowledge of high school students in Bandung, Indonesia about the sources and benefits of vitamin $\mathrm{D}$ based on the major of classes taken in the high school. Bandung is located about almost 800 metres above sea level. Since this city is surrounded by volcanic mountains, it has cooler temperature through the year with sufficient sunlight. With a good knowledge of the source and benefit of vitamin D, it is expected that these adolescents would lead a healthy life later in their lifetime.

\section{METHODS}

This was a quantitative analytical study with a cross-sectional design. This study was conducted in one of public high schools in Bandung in 2019. The school was selected purposively from a total of two Madrasah Aliyah Negeri (MAN) schools, equivalent to public high schools. In Madrasah high schools, female and male were obliged to wear long sleeves uniforms, and hijab covering the head for female. Using sampling for a survey method, a minimum of 100 participants was set, however, all students who were interested to participate were welcomed. Since the age of the students were under 18 years old, which was categorized under vulnerable group, consent was also given by a guardian and in this study by the school principal. After a written permission from the school principal and informed consent from the students, questionnaire about knowledge of vitamin D source and its benefit was distributed. Incomplete questionnaire was excluded.

In brief, questionnaire was first tested before the study started for its validity and reliability, by distributing questionnaires to 30 other high school students who were not part of the respondents. Only valid questions were included in the questionnaire. The Cronbach Alpha value of this questionnaire was 0.68 . The questionnaire consisted of two parts; the first part was about the knowledge of the sources of vitamin D (10 questions) and the second part was about the benefits of vitamin D (4 questions). The correct answer on each question was given a value of 1 and the wrong answer a value of 0 . The knowledge was determined from the percentage of the correct answers. The knowledge score was then compared between gender and between the majors taken in the class, which were Natural or Social Sciences. After filling in the questionnaire, a lecture about vitamin D was given to the high school students, hoping to increase their knowledge about vitamin $\mathrm{D}$. The study was approved by the Ethics Committee of Health Research of Medical Faculty of Universitas Padjadjaran (No. 832/UN6.KEP/EC/2019).

The collected data was processed using SPSS version 22.0, licensed to Universitas Padjadjaran. Data distribution was tested for its normality, and the differences in knowledge between gender and majors were tested with the Mann-Whitney test when data was not normally distributed. A $p$ value of $<0.05$ was considered as a significant difference.

\section{RESULTS}

In total, 205 questionnaires were distributed to the high school students, of which 7 were excluded due to incomplete answers. Thus, there were 198 high school students included in this study, consisting of 151 females (76.3\%) and 47 males $(23.7 \%)$. The major taken by the high school students in the class was the Natural Sciences $(55.6 \%)$ or the Social Sciences (44.4\%).

\section{Knowledge about Sources of Vitamin D}

In general, the average of knowledge about vitamin $\mathrm{D}$ was $72.8 \%$. In detail, the average of students who answered about the source of vitamin D correctly was $61.9 \%$ (Table 1). However, there were several questions of which the percentage of correct answers were below the average, among others (Q2) sunlight contains only a few vitamins D (42.4\%), (Q3) part of eggs containing vitamin D was egg yolk (59.1\%), (Q5) excess body weight could cause vitamin D deficiency (52\%), (Q10) mushroom contained vitamin D (41.9\%).

\section{Knowledge about Benefits of Vitamin D}

The average of respondents who answered questions about the benefits of vitamin D correctly was higher than questions about the sources of vitamin $\mathrm{D}$ which was $83.8 \%$ (Table 2). Again, there were several questions of which the percentage of correct answers were below the average, among others (Q3) vitamin D could help to prevent diabetes (65.7\%) and (Q4) vitamin $\mathrm{D}$ had a function to prevent cancers (82.8\%). 


\section{The knowledge about vitamin $\mathrm{D}$ based on gender and majors in class}

The median of correct numbers about sources and benefits of vitamin $D$ was significantly higher $(\mathrm{p}<0.001)$ among female high school students compared to male students with median of 10 (range 5-14) and 8 (range 3-12), respectively (Table 3). However, the knowledge was not significantly different $(\mathrm{p}=0.227)$ in students majoring in Natural Sciences compared to Social Sciences with median 10 (range 3-14) and 9 (range 3-13), respectively.

\section{DISCUSSION}

The population living in Indonesia where sun exposure is high, has been known to have a low level of vitamin D in their blood. The high sun exposure may relate with avoidance of outdoor activities or dress covered-up. Some information regarding the sun that may increase skin cancer or exacerbate disease may as well given a wrong perception to the general community. ${ }^{19}$ The adolescence is an asset for nation's next generation, a good health education including knowledge on benefit of vitamin will improve their health status in the future.

This study has explored the knowledge about sources and benefits of vitamin $\mathrm{D}$ among high school students in a Madrasah, Bandung, Indonesia. Religious dress such as hijab is a practical barrier to sun exposure, which may contribute to lower vitamin D plasma concentration. Study in Jordan has shown that there is a lower vitamin $\mathrm{D}$ in female, especially among those wearing hijab. ${ }^{20}$ Furthermore, obesity and lifestyle behaviours are directly associated with low level of vitamin D. ${ }^{21}$ Therefore, education to raise awareness about the role of vitamin $\mathrm{D}$ as well as a strategy development to reduce the risk factor for vitamin $\mathrm{D}$ deficiency in female is imperative.

Our study illustrates that almost two third of the respondents have good understanding on source of vitamin D (61.9\%), although there are several aspects that are less known such as the vitamin $\mathrm{D}$ in the sunlight, food sources containing vitamin $\mathrm{D}$ and risk of vitamin $\mathrm{D}$ deficiency among individual with overweight. The students did not fully recognise that the
Table 1. The distribution of correct answers on knowledge about the source of vitamin D

\begin{tabular}{|c|c|c|c|c|c|c|}
\hline \multirow[b]{2}{*}{ No. } & \multirow[b]{2}{*}{ Questions } & \multicolumn{2}{|c|}{ Gender } & \multicolumn{2}{|c|}{ Majors } & \multirow[b]{2}{*}{$\begin{array}{l}\text { TOTAL } \\
\text { N (\%) }\end{array}$} \\
\hline & & $\begin{array}{l}\text { Male } \\
\text { N (\%) }\end{array}$ & $\begin{array}{c}\text { Female } \\
\text { N (\%) }\end{array}$ & $\begin{array}{c}\text { Natural } \\
\text { Sciences } \\
\text { N (\%) }\end{array}$ & $\begin{array}{c}\text { Social } \\
\text { Sciences } \\
\text { N (\%) }\end{array}$ & \\
\hline 1. & $\begin{array}{l}\text { The main sources } \\
\text { of vitamin } \mathrm{D} \text { are } \\
\text { vegetables }\end{array}$ & $19(40)$ & $109(72)$ & $78(70)$ & $50(56)$ & $128(64.6)$ \\
\hline 2. & $\begin{array}{l}\text { Exposure to sunlight } \\
\text { contains only a little } \\
\text { vitamin D that the } \\
\text { body needs }\end{array}$ & $13(27)$ & $71(47)$ & $52(47)$ & $32(36)$ & $84(42.4)^{\star}$ \\
\hline 3. & $\begin{array}{l}\text { Which part of the egg } \\
\text { that contains vitamin } \\
D ?\end{array}$ & $23(48)$ & $94(62)$ & $64(58)$ & $53(60)$ & $117(59.1)^{\star}$ \\
\hline 4. & $\begin{array}{l}\text { Which fish contain } \\
\text { vitamin } \mathrm{D} \text { ? }\end{array}$ & $29(61)$ & $95(63)$ & $72(65)$ & $52(59)$ & $124(62.6)$ \\
\hline 5. & $\begin{array}{l}\text { Overweight can cause } \\
\text { vitamin D deficiency }\end{array}$ & $29(61)$ & $74(49)$ & $52(47)$ & $51(58)$ & $103(52)^{\star}$ \\
\hline 6. & $\begin{array}{l}\text { The use of vitamin D } \\
\text { supplements can cause } \\
\text { kidney stones }\end{array}$ & $27(57)$ & $108(71)$ & $75(68)$ & $60(68)$ & $135(68.2)$ \\
\hline 7. & $\begin{array}{l}\text { What kind of drinks } \\
\text { contain vitamin } \mathrm{D} \text { ? }\end{array}$ & $40(85)$ & $137(90)$ & $99(90)$ & $78(88)$ & $177(89.4)$ \\
\hline 8. & $\begin{array}{l}\text { Which food can } \\
\text { increase vitamin D } \\
\text { intake? }\end{array}$ & $25(53)$ & $102(67)$ & $73(66)$ & $54(61)$ & $127(64.1)$ \\
\hline 9. & $\begin{array}{l}\text { Which food can } \\
\text { increase vitamin D } \\
\text { intake? }\end{array}$ & $26(55)$ & $122(80)$ & $82(74)$ & $66(75)$ & $148(74.7)$ \\
\hline 10. & $\begin{array}{l}\text { Which foods contain } \\
\text { vitamin D? }\end{array}$ & $8(17)$ & $75(49)$ & $60(54)$ & $23(26)$ & $83(41.9)^{\star}$ \\
\hline & AVERAGE & $24(51)$ & $99(65.5)$ & $70(63.6)$ & $52(59)$ & $123(61.9)$ \\
\hline
\end{tabular}

Note: ${ }^{*}$ total correct answers are less than the average $(61.9 \%)$

Table 2. The distribution of correct answers of knowledge about the benefit of vitamin D

\begin{tabular}{|c|c|c|c|c|c|c|}
\hline \multirow{3}{*}{ No. } & \multirow{3}{*}{ Questions } & \multicolumn{2}{|c|}{ Gender } & \multicolumn{2}{|c|}{ Majors } & \multirow{3}{*}{$\begin{array}{l}\text { TOTAL } \\
\text { N (\%) }\end{array}$} \\
\hline & & & & $\begin{array}{l}\text { Natural } \\
\text { Sciences }\end{array}$ & $\begin{array}{c}\text { Social } \\
\text { Sciences }\end{array}$ & \\
\hline & & N (\%) & $\mathbf{N}(\%)$ & N (\%) & N (\%) & \\
\hline 1. & $\begin{array}{l}\text { Vitamin D is } \\
\text { beneficial in } \\
\text { absorption of calcium, } \\
\text { needed for bones and } \\
\text { teeth }\end{array}$ & $46(97)$ & $146(96)$ & $108(98)$ & $84(95)$ & $192(97)$ \\
\hline 2. & $\begin{array}{l}\text { Vitamin D is } \\
\text { beneficial in the } \\
\text { immune system }\end{array}$ & $39(82)$ & $138(91)$ & $98(89)$ & $79(89)$ & $177(89.4)$ \\
\hline 3. & $\begin{array}{l}\text { Adequate intake } \\
\text { of Vitamin D can } \\
\text { prevent diabetes }\end{array}$ & $22(46)$ & $108(71)$ & $74(67)$ & $56(63)$ & $130(65.7)^{\star}$ \\
\hline 4. & $\begin{array}{l}\text { Adequate intake } \\
\text { of Vitamin D can } \\
\text { prevent cancers }\end{array}$ & $30(63)$ & $134(88)$ & $91(82)$ & $73(82)$ & $164(82.8)^{\star}$ \\
\hline
\end{tabular}

$\begin{array}{llllll}\text { AVERAGE } & 34(72.3) & 132(87.4) & 93(84.5) & 73(82.9) & 166(83.8)\end{array}$

Note: ${ }^{*}$ total correct answers are less than the average (83.8\%) 
Table 3. Difference of knowledge about vitamin D, based on gender and majors in class

\begin{tabular}{lccc}
\hline \multicolumn{1}{c}{ Characteristics } & Median & $\begin{array}{c}\text { Range } \\
\text { Min-Max }\end{array}$ & p value* \\
\hline Gender & 8 & $3-12$ & $<0.001^{* *}$ \\
$\quad$ Male & 10 & $5-14$ & \\
$\quad$ Female & & & 0.227 \\
Majors & 10 & $3-14$ & \\
$\quad$ Natural Sciences & 9 & $3-13$ & \\
Social Sciences & & & \\
\hline
\end{tabular}

* Mann Whitney Test; ${ }^{* *}$ statistical significant different $\mathrm{p}<0.05$

majority (80-90\%) source of vitamin D comes from sunlight. ${ }^{18}$ Some respondents in our study (35.4\%) still thought that the vegetables were the main source of vitamin $\mathrm{D}$, even though food only account for $10-20 \%$ of vitamin D need. ${ }^{22}$ Regarding source of vitamin $\mathrm{D}$ in the food, egg yolk is rich in vitamins $\mathrm{A}, \mathrm{D}, \mathrm{E}, \mathrm{K}, \mathrm{B} 1, \mathrm{~B} 2, \mathrm{~B} 5$, $\mathrm{B} 6, \mathrm{~B} 9$, and $\mathrm{B} 12$, but not vitamin $\mathrm{C}$. The vitamin $\mathrm{D}$ content in egg yolk is $20 \mathrm{IU} /$ egg. In other part of the egg such as the egg whites contains only vitamins B2, B3, and B5.22

Mushrooms contain vitamin D 100$1600 \mathrm{IU} / 3.5 \mathrm{oz} .{ }^{22}$ Only half of the students in our study knew that mushroom was high in vitamin D. Being overweight or obese may reduce the bioavailability of vitamin $\mathrm{D}$ that come from both foods and sunlight. Vitamin D is a fat-soluble vitamin which can be deposited in fat tissue, leading to lower vitamin D levels in the blood of obese individuals, therefore, obesity may lead to vitamin D deficiency. ${ }^{23}$ Furthermore, the excess of body weight may be harmful for not only vitamin D deposit, but also for other disease as a risk factor.

The majority $(83.8 \%)$ of the students had good understanding on the benefits of vitamin $\mathrm{D}$, however, there were less understanding on the function of vitamin $\mathrm{D}$ in preventing diabetes and cancer. Vitamin $D$ can stimulate pancreatic beta-cell secretion, thereby increasing insulin secretion which is a hormone to regulate blood sugar levels. Thus, vitamin $\mathrm{D}$ deficiency is associated with a risk of insulin deficiency which causes an increased risk of developing of diabetes mellitus. ${ }^{24}$ Vitamin D can control more than 200 genes for cell proliferation, differentiation, and apoptosis so that it can reduce the risk of cancer development. In an epidemiological study, it has been found that vitamin $\mathrm{D}$ deficiency was associated with a $30-50 \%$ increased risk of colon, prostate and breast cancer. ${ }^{25}$ Improving health education about the benefits of vitamin $\mathrm{D}$, especially to prevent diabetes and cancer, may give a valuable information for long-term purposes.

Our study has shown that knowledge in vitamin $\mathrm{D}$ sources and benefits is better in female students than in males $(\mathrm{p}<0.001)$, similar to studies carried out in Vietnam, ${ }^{26}$ and India. ${ }^{27}$ Interestingly, a study in Saudi Arabia shows that female participants are more enthusiastic in taking action to improve their vitamin D status, for example that they start taking vitamin D supplements after consulting to their doctors. Furthermore, they also like to expose themselves in the sun to increase their serum vitamin D levels. ${ }^{28}$

Not only regarding vitamin $\mathrm{D}$, female, in general, has more knowledge around nutrition facts. As shown in a study among college students, females are more interested in diet, nutrition, and body weight than males. ${ }^{29}$ According to the National Institute of Public Health in Poland, in average, males are indeed not keen in matters concerning nutrition, therefore, the knowledge among males about food, nutrition, lifestyle and its relationship with health is lower. ${ }^{30}$ With a better knowledge and motivation, female adolescents can be agents of change to increase public knowledge as they will later become a mother who can educate their children and their families. ${ }^{31}$ Conversely, lack of knowledge in male adolescents can be a suggestion for health workers to increase knowledge among males with some intervention and education. ${ }^{32}$
High school students majoring in Natural Sciences might have better knowledge in Biology rather than students majoring in Social Sciences. Although we found students majoring in Natural Sciences have higher knowledge score, the difference was not statistically significant ( $p>0.05)$. The students have learned in the Biology subject several nutrition topics, however, education on nutrition including vitamin $\mathrm{D}$ can also be obtained informally from other source apart from school, for example from family, community, social media and others. ${ }^{33}$ The success of community-based health promotion and prevention depends on the knowledge and behaviour of members in the community.

There are several limitations in this study. Firstly, the data collection using a questionnaire is highly dependent on how serious the respondents in filling in the questionnaire. Moreover, the questionnaire in our study has been given only once, which is before the health education. Alternatively, questionnaire after lecture should be employed to explore the knowledge increase. This study is also conducted in only one Islamic high school in Bandung, therefore, its generalisability to broader high school students may be limited.

\section{CONCLUSIONS}

High school students have a relatively good knowledge on vitamin $\mathrm{D}$, although some aspects need improvement. The knowledge about the source of vitamin D and its benefit among female high school students is significantly better than males. We suggest an integrative health education and outdoor activities for sun exposure as well as a nutrition program for preparing good meals focusing especially on male students and the Social Sciences Class, hoping this will contribute to reduce vitamin $\mathrm{D}$ deficiency among adolescence in Indonesia.

\section{ACKNOWLEDGEMENT}

We are grateful to the school principal of MAN2 Bandung and the students who participated in this study.

\section{AUTHOR CONTRIBUTION}

Research conception and design: ES and 
VYKD; experiment: RSG, ES and VYKD; statistical analysis of the data: RSG, ES and VYKD; interpretation of the data RSG, ES and VYKD; writing of the manuscript: RSG, ES and VYKD

\section{CONFLICT OF INTEREST}

No conflicts of interest to be declared.

\section{FUNDING}

This study was financially supported by internal grant from Universitas Padjadjaran 2019 as part of our community service.

\section{REFERENCES}

1. Pludowski P, Holick MF, Grant WB, Konstantynowicz J, Mascarenhas MR, Haq A, et al. Vitamin D supplementation guidelines. J Steroid Biochem Mol Biol. 2018; 175: 125-135.

2. Wang H, Chen W, Li D, Yin X, Zhang X, Olsen $\mathrm{N}$, et al. Vitamin D and chronic diseases. Aging Dis. 2017; 8(3): 346-353.

3. Hoel DG, de Gruijl FR. Sun exposure public health directives. Int $J$ Environ Res Public Health. 2018; 15(12).

4. Binkley N, Ramamurthy R, Krueger D. Low vitamin $\mathrm{D}$ status: definition, prevalence, consequences, and correction. Endocrinol Metab Clin North Am. 2010; 39(2): 287-301.

5. Hu, Yichun, Jing Chen, Rui Wang, Min Li, Chunfeng Yun, et al. 2017. Vitamin D nutritional status and its related factors for Chinese children and adolescents in 20102012. Nutrients. 9(9): 1-10.

6. Sari DK, Damanik HA, Lipoeto NI, Lubis Z. Is micro evolution in tropical country women resulting low 25(OH)D level?: a cross sectional study in Indonesia. J Nutr Food Sci. 2013; 4(10.4172): 2155-9600.1000246

7. Soesanti F, Pulungan A, Tridjaja B, Batubara JR. Vitamin D profile in healthy children aged 7-12 years old in Indonesia. Int J Pediatr Endocrinol. 2013; 2013(S1): 9856.

8. Saptarini, Dyah. Status vitamin D pada remaja sehat usia 15-18 tahun di Kota Depok [Vitamin D status in healthy youth aged 15-18 years old in Depok City]. Journal Indonesia Medical Association. 2019; 69(2): 71-77.

9. Holick MF. Resurrection of vitamin D deficiency and rickets. J Clin Invest. 2006; 116(8):2062-72.
10. Wacker M, Holick MF. Vitamin D - effects on skeletal and extra-skeletal health and the need for supplementation. Nutrients. 2013; 5(1): 111-48.

11. Holick MF. Vitamin D deficiency. $N$ Engl $J$ Med. 2007; 357(3): 266-81.

12. Black LJ, Walton J, Flynn A, Kiely M. Adequacy of vitamin D intakes in children and teenagers from the base diet, fortified foods and supplements. Public Health Nutr. 2014; 17(4): 721-31.

13. Abrams SA. Calcium and vitamin D requirements for optimal bone mass during adolescence. Curr Opin Clin Nutr Metab Care. 2011; 14(6): 605-9.

14. Stewart NF, Lewis SN. Vitamin D deficiency in adolescents in a tier 4 psychiatric unit. BJPsych Bull. 2017; 41(03): 133-6.

15. Fikawati S, Syafiq A, Puspasari P. Faktor-faktor yang berhubungan dengan asupan kalsium pada remaja di Kota Bandung [Factors related to adolescent calsium intake in Bandung City]. Universa Med. 2005; 24(1): 24-34.

16. Barrack MT, van Loan MD, Rauh MJ, Nichols JF. Physiologic and behavioral indicators of energy deficiency in female adolescent runners with elevated bone turnover. Am J Clin Nutr. 2010; 92(3): 652-9.

17. Voo VTF, Stankovich J, O’Brien TJ, Butzkueven $\mathrm{H}$, Monif M. Vitamin D status in an Australian patient population: a large retrospective case series focusing on factors associated with variations in serum 25(OH)D. BMJ Open. 2020; 10(3): e032567.

18. Ho-Pham L, Nguyen M. Survey on knowledge and attitudes on vitamin D and sunlight exposure in an urban population in Vietnam. $J$ ASEAN Fed Endocr Soc. 2014; 27(2): 191-5.

19. Kotta S, Gadhvi D, Jakeways N, Saeed M, Sohanpal R, Hull S, et al. Test me and treat me - attitudes to vitamin D deficiency and supplementation: a qualitative study. $B M J$ Open. 2015; 5(7): e007401.

20. Batieha A, Khader Y, Jaddou H, Hyassat D, Batieha Z, Khateeb M, et al.. Vitamin D status in Jordan: dress style and gender discrepancies. Ann Nutr Metab. 2011; 58(1): 10-8.

21. Mithal A, Wahl DA, Bonjour JP, Burckhardt P, Dawson-Hughes B, Eisman JA, et al. Global vitamin D status and determinants of hypovitaminosis D. Osteoporos Int. 2009; 20(11): 1807-20.

22. Réhault-Godbert S, Guyot N, Nys Y. The golden egg: nutritional value, bioactivities, and emerging benefits for human health. Nutrients. 2019; 11(3).
23. Bhongir AV, Vijaitha SM, Kuruguntla $S$, Yalamati P, Vyakaranam S. Association of vitamin $\mathrm{D}$ and parathyroid hormone levels in overweight and obese adolescents. Indian J Clin Biochem. 2020; 35(1): 95-101.

24. Grant WB. Review of recent advances in understanding the role of vitamin D in reducing cancer risk: breast, colorectal, prostate, and overall cancer. Anticancer Res. 2020; 40(1): 491-499.

25. Poh BK, Rojroongwasinkul N, Nguyen BK, Sandjaja, Ruzita AT, Yamborisut U, et al. 25-hydroxy-vitamin $\mathrm{D}$ demography and the risk of vitamin D insufficiency in the South East Asian Nutrition Surveys (SEANUTS). Asia Pac J Clin Nutr. 2016; 25(3): 538-48.

26. Arora H, Dixit V, Srivastava N. Evaluation of knowledge, practices of vitamin $\mathrm{D}$ and attitude toward sunlight among Indian students. Asian J Pharm Clin Res. 2016; 9(1): 308-313.

27. Aljefree N, Lee P, Ahmed F. Exploring knowledge and attitudes about vitamin D among adults in Saudi Arabia: a qualitative study. Healthcare (Basel). 2017; 5(4).

28. Yahia N, Brown CA, Rapley M, Chung M. Level of nutrition knowledge and its association with fat consumption among college students. $B M C$ Public Health. 2016; 16(1): 1047.

29. Kołłajtis-Dołowy A, Żamojcin K. The level of knowledge on nutrition and its relation to health among Polish young men. Rocz Panstw Zakl Hig. 2016; 67(2): 155-61.

30. Wardle J, Haase AM, Steptoe A, Nillapun $\mathrm{M}$, Jonwutiwes K, Bellisle F. Gender differences in food choice: the contribution of health beliefs and dieting. Ann Behav Med. 2004; 27(2): 10716.

31. Sohl E, Heymans MW, De Jongh RT, Den Heijer M, Visser M, Merlijn T, et al. Prediction of vitamin $\mathrm{D}$ deficiency by simple patient characteristics. Am J Clin Nutr. 2014; 99(5): 1089-95.

32. Ruppert L, Køster B, Siegert AM, Cop C, Boyers L, Karimkhani C, et al. YouTube as a source of health information: analysis of sun protection and skin cancer prevention related issues. Dermatol Online J. 2017; 23(1).

33. Farahati J, Nagarajah J, Gilman E, Mahjoob S, Zohreh M, Rosenbaum-Krumme S, et al. Ethnicity, clothing style, and body mass index are significant predictors of vitamin D insufficiency in Germany. Endocr Pract. 2015; 21(2): 122-7.

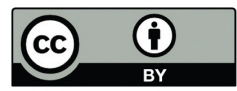

This work is licensed under a Creative Commons Attribution 